\title{
Kalimat Imperatif dalam Film Yeoljeong-Gateun Soriha-Go Iss-Ne
}

\author{
Imperative Sentence in Yeoljeong-Gateun Sori-Hago Iss-Ne Movie
}

\author{
Ratih Ratna Perdana ${ }^{1}, \mathbf{U s m i}^{2}$ \\ Universitas Indonesia \\ ratih.ratna61@ui.ac.id ${ }^{1}$ \\ usmi07@ui.ac.id²
}

\begin{abstract}
When communicating, humans as speakers of language will arrange words into meaningful sentences so listeners can understand the purpose of the speech. The speaker will determine the type of sentences and variety of language to use. In the event of spoken communication, there are various types of speech, one of which is imperative sentence speech. This research aims to analyze speech acts that uses imperative sentences in a film entitled Yeoljeong-gateun Soriha-go Iss-ne (열정같은 소리하고 있네). This research applies descriptive method with quantitative and qualitative approaches. Data were collected by applying note-taking techniques. The data were further identified and classified based on the imperative sentence theory by Lee (2016). The result of this study showed that 175 imperative sentences were found in the film corpus. These can be classified into 8 types of speech acts, namely speech acts of commands $(43,4 \%)$, demands $(28,6 \%)$, permission $(6,9 \%)$, suggestion $(5,7 \%)$, prohibition $(5,1 \%)$, warning $(5,1 \%)$, greeting $(2,9 \%)$, and requests $(2,3 \%)$. Meanwhile, the most used variety of languages in the film corpus is informal language or haeche with 132 sentences.
\end{abstract}

Keywords: Korean language, imperative sentence, variety of language, sentence final ending, speech act.

\section{INTISARI}

Ketika berkomunikasi, manusia sebagai penutur bahasa akan merangkai kata-kata menjadi kalimat yang berterima supaya mitra tutur dapat memahami maksud tuturannya. Seorang penutur akan menentukan jenis kalimat dan ragam bahasa yang akan ia gunakan sesuai konteks berkomunikasi. Dalam peristiwa tutur, terdapat berbagai jenis tuturan, salah satunya tuturan kalimat imperatif. Penelitian ini bertujuan untuk menganalisis tindak tutur berwujud kalimat imperatif berbahasa Korea dalam film berjudul Yeoljeong-gateun Soriha-go Iss-ne (열정같은 소리하고 있네). Penelitian ini merupakan penelitian deskriptif dengan pendekatan kuantitatif dan kualitatif. Pengumpulan data menggunakan teknik simak catat. Selanjutnya, data yang diperoleh diidentifikasi dan diklasifikasikan berdasarkan teori kalimat imperatif yang dikemukakan oleh Lee (2016). Hasil penelitian menunjukkan bahwa dalam korpus film ditemukan 175 tuturan kalimat imperatif. Seratus tujuh puluh lima kalimat tersebut dapat diklasifikasikan ke dalam 8 jenis tindak tutur, yakni tindak tutur memerintah $(43,4 \%)$, meminta $(28,6 \%)$, memberi persetujuan $(6,9 \%)$, memberi saran $(5,7 \%)$, melarang $(5,1 \%)$, memberi peringatan $(5,1 \%)$, memberi salam $(2,9 \%)$, dan mengajak $(2,3 \%)$. Sementara itu, ragam bahasa yang paling banyak digunakan dalam korpus film ini adalah ragam bahasa informal atau haeche sebanyak 132 kalimat.

Kata kunci: bahasa Korea, kalimat imperatif, ragam bahasa, akhiran penutup kalimat, tindak tutur

Saran sitasi:

Perdana, R.R., Usmi (2021). Kalimat Imperatif dalam Film Yeoljeong-Gateun Soriha-Go Iss-Ne. JLA (Jurnal Lingua Applicata), 4(2), 74-88.

\footnotetext{
${ }^{1}$ First author

${ }^{2}$ Corresponding author
} 


\section{PENDAHULUAN}

Manusia membutuhkan bahasa untuk saling berkomunikasi. Adanya bahasa membuat manusia dapat mengekspresikan tujuan, maksud, dan perasaan yang dirasakan. Bahasa menurut Keraf (1997: 1) memiliki dua pengertian. Pengertian pertama adalah bahasa sebagai alat komunikasi antar anggota masyarakat yang berupa simbol bunyi dan dihasilkan oleh alat ucap manusia. Pengertian kedua adalah bahasa sebagai sistem komunikasi yang menggunakan simbol-simbol vokal yang bersifat arbitrer. Dengan demikian, dapat disimpulkan bahwa bahasa merupakan alat komunikasi yang digunakan manusia berupa simbol vokal yang telah disepakati oleh lingkungan pengguna bahasa.

Ketika berkomunikasi, manusia sebagai penutur bahasa akan merangkai kata-kata menjadi tuturan atau kalimat yang berterima supaya mitra tutur dapat memahami maksud tuturannya. Kalimat yang berterima disusun sesuai dengan kaidah bahasa yang berlaku di lingkungan pengguna bahasa tersebut. Seorang penutur akan menentukan jenis kalimat yang akan diucapkan sesuai dengan fungsinya. Berdasarkan fungsinya, kalimat dalam bahasa Korea dapat terbagi menjadi lima jenis kalimat, yaitu kalimat interogatif (uimunmun, 의문문), kalimat deklaratif (pyeongseomun, 평서문), kalimat imperatif (myeongryeongmun, 명령문), kalimat seruan (gamtanmun, 감탄문), dan kalimat persuasif (cheongyumun, 청유문) (Nam \& Go, 1985; Lee \& Ramsey, 2000; Qonita dan Usmi, 2019). Ketika menuturkan sebuah kalimat, penutur memiliki maksud tindakannya sendiri. Misalnya, penutur menuturkan kalimat imperatif tetapi ia memiliki maksud untuk meminta kepada mitra tutur. Hal ini disebut dengan tindak tutur. Tindak tutur dapat diwujudkan dengan menggunakan berbagai bentuk atau pola kalimat, di antaranya pola kalimat pernyataan, ajakan, dan permintaan. Pada penelitian ini, peneliti akan berfokus pada kalimat imperatif.

Seorang penutur juga akan mempertimbangkan ragam bahasa yang digunakan berdasarkan kedudukan mitra tutur dan situasi penuturan. Dalam bahasa Korea terdapat enam tingkat ragam bahasa, yakni ragam bahasa formal (hapsyoche, 합쇼체), semiformal (haoche, 하오체), familiar (hageche, 하게체), setara (haerache, 해라체), informal santun (haeyoche, 해요체), dan informal (haeche, 해체) (Lee, 2005; Jeong \& Lee, 2005). Ragam bahasa dan jenis kalimat dalam bahasa Korea dapat diidentifikasi dan dibedakan melalui penggunaan akhiran penutup kalimat (jonggyeol eomi, 종결어미) (Lee \& Ramsey, 2000: 83). Dengan kata lain, ragam bahasa dan jenis kalimat dalam bahasa Korea ditentukan oleh penggunaan akhiran penutup kalimat. Selain itu, penggunaan akhiran penutup kalimat tertentu juga dapat menunjukkan tingkat kesantunan sebuah tuturan. Dalam penelitian ini, peneliti akan menggunakan semua jenis ragam bahasa yang terdapat pada bahasa Korea.

Korpus penelitian ini menggunakan film berjudul Yeoljeong-gateun Soriha-go Iss-ne (열정같은 소리하고 있네) yang dalam bahasa Inggris berarti "You Call it Passion" 
karena tuturan kalimat imperatif banyak ditemukan di film berlatar dunia kerja. Film ini pertama kali ditayangkan pada November 2015 dengan durasi 106 menit. Film ini menceritakan kesulitan seorang wanita muda bernama Do Rahui yang bekerja di sebuah kantor berita dunia hiburan. Fokus kajian dirumuskan ke dalam dua pertanyaan penelitian. Pertama, bagaimana tindak tutur berwujud kalimat imperatif dalam korpus film Yeoljeonggateun Soriha-go Iss-ne? Kedua, bagaimana ragam bahasa yang digunakan dalam tuturan kalimat imperatif dalam korpus film tersebut? Penelitian ini diharapkan dapat memberikan kontribusi terhadap literatur linguistik bahasa Korea, khususnya kalimat imperatif bahasa Korea.

\section{METODE PENELITIAN}

Penelitian ini merupakan penelitian deskriptif dengan pendekatan kuantitatif dan kualitatif. Sumber data penelitian adalah tuturan dalam film Yeoljeong-gateun Soriha-go Iss-ne yang diambil dengan teknik simak catat. Dalam penelitian ini, penulis menggunakan tiga teori untuk menganalisis data tuturan kalimat imperatif yang telah diidentifikasi dalam korpus data. Teori pertama, yakni teori Lee (2016), digunakan untuk mengklasifikasi dan menganalisis tindak tutur berwujud kalimat imperatif bahasa Korea. Kedua teori lainnya, yakni teori Lee (2005) dan Jeong \& Lee (2005), digunakan untuk menganalisis ragam bahasa kalimat imperatif bahasa Korea. Kedua teori ini digunakan untuk menganalisis ragam bahasa karena kedua teori ini saling melengkapi.

\section{LANDASAN TEORI}

\section{Kalimat Imperatif dan Tindak Tutur}

Bahasa Korea

Kalimat imperatif adalah kalimat yang mengandung perintah atau permintaan supaya orang lain melakukan sesuatu sesuai dengan keinginan orang yang memberi perintah (Keraf, dalam Rahardi, 2005: 27). Hal ini senada dengan Nam \& Go (1985) yang mendefinisikan kalimat imperatif sebagai kalimat yang digunakan oleh penutur untuk meminta mitra tutur melakukan sesuatu sesuai dengan tujuannya. Kalimat imperatif dalam bahasa Korea dapat dibedakan menjadi dua jenis, yaitu kalimat imperatif positif (geungjeong myeongryeongmun, 긍정 명령문) dan kalimat imperatif negatif (bujeong myeongryeongmun, 부정 명령문) (Im, 1987: 73). Kalimat imperatif positif adalah kalimat imperatif yang diucapkan berdasarkan listener's future action atau aksi yang akan dilakukan oleh mitra tutur, sedangkan kalimat imperatif negatif adalah kalimat imperatif yang menggunakan prefinal ending (seoneomal eomi) -ji ma (-지 마-) yang berarti ‘jangan' sebelum dilekatkan dengan akhiran penutup kalimat (jonggyeol eomi) sesuai dengan ragam bahasa. Berikut ini adalah contoh kalimat imperatif bahasa Korea.

(1) 차에 빨리 타십시오.

Cha-e ppalli ta-sipsio.

Cepat naik ke mobil. 
(2) 매운 음식을 많이 먹지 마라.

Maeun eumsig-eul manhi meog-ji ma-ra.

Jangan terlalu banyak makan makanan pedas.

Kalimat (1) merupakan kalimat imperatif positif, sedangkan kalimat (2) adalah kalimat imperatif negatif. Kalimat (1) tidak menggunakan pre-final ending negatif. Kalimat (2) menggunakan pre-final ending -ji ma- yang menjadi pembeda antara kalimat imperatif positif dan kalimat imperatif negatif.

Lebih lanjut, tindak tutur ( $h$ wahaeng, 화행) adalah makna tindakan dari tuturan yang dibuat oleh penutur dan tindak tutur berkaitan dengan niat penutur dalam menuturkan suatu kalimat (Yu, 2009: 3). Tindak tutur adalah sikap yang diungkapkan oleh penutur ketika berkomunikasi ( $\mathrm{Gu}$ et al, 2018: 808). Dengan demikian, dapat dikatakan bahwa tindak tutur merupakan sikap penutur yang berkaitan dengan niat penutur dalam berkomunikasi.

Dalam hal ini, Lee (2016: 64) menyatakan bahwa kalimat imperatif dalam bahasa Korea dapat mengandung 11 tindak tutur, yang dapat dibedakan berdasarkan maksud penutur ketika menggunakan kalimat imperatif. Sebagian besar tindak tutur berwujud kalimat imperatif yang dikemukakan oleh Lee ini diadopsi dari tindak tutur yang dikemukakan oleh Quirk et al. (1985). Tabel 1 menunjukkan 11 tindak tutur berwujud kalimat imperatif dalam bahasa Korea.
Berdasarkan Tabel 1, dapat diketahui bahwa kalimat imperatif bahasa Korea dapat mewujudkan 11 tindak tutur. Pertama, tindak tutur memerintah (jisi, 지시/myeongryeong, 명령). Tindak tutur ini merupakan tindak tutur yang paling sering digunakan oleh penutur. Tindak tutur ini digunakan ketika penutur memerintah mitra tutur untuk mencapai tujuan. Tindak tutur memerintah dapat digunakan oleh penutur yang memiliki kedudukan lebih rendah dari mitra tutur asalkan memperhatikan ragam bahasa yang sesuai.

Kedua, tindak tutur meminta (yogu, 요구/yocheong, 요청). Berdasarkan Kim dalam Xia (2013), tindak tutur meminta digunakan ketika penutur meminta hal yang dapat dilakukan oleh mitra tutur. Oleh sebab itu, jika mitra tutur merasa terbebani dengan permintaan penutur, mitra tutur dapat tidak mengabulkan permintaan tersebut. Ketika menggunakan tindak tutur ini, penutur dapat menggunakan kata jom (좀) untuk menambahkan kesantunan tuturan.

Ketiga, tindak tutur melarang (geumji, 금지). Tindak tutur ini dapat dikategorikan sebagai kalimat imperatif negatif (bujeong myeongryeongmun, 부정 명령문) karena menggunakan pre-final ending (seoneomal eomi, 선어말 어미) -ji ma (-지 마) yang berarti 'jangan'. Tindak tutur melarang ini digunakan supaya mitra tutur tidak melakukan hal yang telah dituturkan oleh penutur atau penulis.

Keempat, tindak tutur memberi keleluasaan (yangbo, 양보). Tindak tutur ini digunakan ketika penutur merasa jika mitra 
tutur tidak mampu untuk melakukan suatu hal. Umumnya, tindak tutur ini digunakan dengan memberikan alasan terlebih dahulu. Ketika menggunakan tindak tutur ini, penutur dapat menggunakan kalimat imperatif negatif (bujeong myeongryeongmun, 부정 명령문) dengan memberikan alasan terlebih dahulu supaya dapat dibedakan dengan tindak tutur melarang.

Tabel 1. Tindak Tutur yang Diwujudkan dalam Bentuk Kalimat Imperatif

\begin{tabular}{|c|c|}
\hline Tindak Tutur & Contoh Kalimat Imperatif \\
\hline $\begin{array}{l}\text { (1) Memerintah } \\
\text { (jisi, 지시/myeongryeong, 명령) }\end{array}$ & $\begin{array}{l}\text { 문을 닫아라. } \\
\text { Mun-eul dad-ara. } \\
\text { Tutup pintunya. }\end{array}$ \\
\hline $\begin{array}{l}\text { (2) Meminta } \\
\text { (yogu, 요구/yocheong, 요청) }\end{array}$ & $\begin{array}{l}\text { 선생님, 수학을 너무 어려워서 다시 가르쳐 주세요. } \\
\text { Seonsaeng-nim, suhag-eul neomu eoryeowo-seo dasi } \\
\text { gareuchyeo juseyo. } \\
\text { Pak/Bu guru, karena matematika sangat sulit tolong } \\
\text { ajarkan saya lagi. }\end{array}$ \\
\hline $\begin{array}{l}\text { (3) Melarang } \\
\text { (geumji, 금지) }\end{array}$ & $\begin{array}{l}\text { 핸드폰을 사용하지 마십시오. } \\
\text { Haendeupon-eul sayongha-ji ma-sibsio. } \\
\text { Jangan menggunakan telepon genggam. }\end{array}$ \\
\hline $\begin{array}{l}\text { (4) Memberi keleluasaan } \\
\text { (yangbo, 양보) }\end{array}$ & $\begin{array}{l}\text { 이거 너무 어려운데 네가 쓰지 마. } \\
\text { Igeo neomu eoryeou-nde nega sseu-ji ma. } \\
\text { Ini sangat sulit, kamu jangan menulis ini. }\end{array}$ \\
\hline $\begin{array}{l}\text { (5) Memberi saran } \\
\text { (gwongo, 권고/jean, 제안/chunggo, 충고) }\end{array}$ & $\begin{array}{l}\text { 지금 } 12 \text { 시이니까 집에 가면 조심해. } \\
\text { Jigeum yeoldusii-nikka jib-e ga-myeon josimhae. } \\
\text { Sekarang sudah jam 12, kamu hati-hati ya ketika } \\
\text { pulang. }\end{array}$ \\
\hline $\begin{array}{l}\text { (6) Memberi peringatan } \\
\text { (gyeonggo, 경고/wihyeop, 위협) }\end{array}$ & $\begin{array}{l}\text { 네가 이런 짓을 다시 해 봐라. } \\
\text { Nega ireon jis-eul dasi hae bwara. } \\
\text { Cobalah untuk melakukan hal ini lagi. }\end{array}$ \\
\hline $\begin{array}{l}\text { (7) Memberi persetujuan } \\
\text { (heorak, 허락) }\end{array}$ & $\begin{array}{l}\text { 네가 그렇게 하고 싶으면 해라. } \\
\text { Nega geroge hago sip-eumyeon haera. } \\
\text { Kalau kamu ingin melakukan ini, lakukanlah. }\end{array}$ \\
\hline $\begin{array}{l}\text { (8) Memperlihatkan harapan } \\
\text { (giwon, 기원) }\end{array}$ & $\begin{array}{l}\text { 비야, 빨리 내려오라! } \\
\text { Bi-ya, ppalli naeryeora! } \\
\text { Hujan, cepat turun! }\end{array}$ \\
\hline $\begin{array}{l}\text { (9) Memberi salam } \\
\text { (chukwon, 축원/insa, 인사) }\end{array}$ & $\begin{array}{l}\text { 안녕히 가세요. } \\
\text { Annyeonghi gase-yo. } \\
\text { Selamat tinggal. }\end{array}$ \\
\hline $\begin{array}{l}\text { (10) Memaki dan mengutuk } \\
\text { (jeoju, 저주) }\end{array}$ & $\begin{array}{l}\text { 나가 죽어! } \\
\text { Naga jugeo! } \\
\text { Mati kau! }\end{array}$ \\
\hline $\begin{array}{l}\text { (11) Mengajak } \\
\text { (cheongyu, 청유) }\end{array}$ & $\begin{array}{l}\text { 내가 노래를 할테니까 너도 해 봐. } \\
\text { Naega norae-reul haltenikka neo-do hae bwa. } \\
\text { Aku akan bernyanyi, jadi kamu juga coba } \\
\text { bernyanyi. }\end{array}$ \\
\hline
\end{tabular}

(Sumber: Lee, 2016)

Kelima, tindak tutur memberi saran atau menasihati (gwongo, 권고/jean, 제안/ chunggo, 충고). Tindak tutur memberi saran ini digunakan ketika penutur memberikan saran atau nasihat mengenai suatu hal yang harus dilakukan oleh mitra tutur demi kebaikan mitra tutur. Dalam hal ini, Mitra tutur dapat memilih untuk melakukan atau 
tidak melakukan saran yang diberikan penutur.

Keenam, tindak tutur memberi peringatan (gyeonggo, 경고/wihyeop, 위협). Ketika penutur bermaksud untuk memberi peringatan, biasanya kalimat yang dituturkan diikuti dengan nada mengancam. Nada mengancam ini sebagai penanda tindak tutur memberi peringatan. Jika tidak diikuti dengan nada mengancam, maka kalimat imperatif tersebut hanya akan menjadi kalimat imperatif yang menyampaikan tindak tutur memerintah.

Ketujuh, tindak tutur memberi persetujuan (heorak, 허락). Tindak tutur ini digunakan ketika penutur menyetujui atau memperbolehkan mitra tutur untuk melakukan hal yang diminta oleh mitra tutur.

Kedelapan, tindak tutur memperlihatkan harapan (giwon, 기원). Tindak tutur ini digunakan ketika seseorang mengharapkan suatu hal yang baik. Tindak tutur ini banyak diwujudkan dengan kalimat imperatif yang menggunakan akhiran penutup kalimat (jonggyeol eomi) -ra, -obsoseo, -eo/a ra, dan -seyo.

Kesembilan, tindak tutur memberi salam (chukwon, 축원/insa, 인사). Dalam bahasa Korea, ungkapan salam banyak dituturkan dengan kalimat imperatif yang ditandai dengan akhiran -seyo. Kalimat imperatif yang memiliki tindak tutur ini, biasanya mengandung harapan baik yang ditujukan untuk mitra tutur.

Kesepuluh, tindak tutur memaki dan mengutuk (jeoju, 저주). Tindak tutur ini diucapkan oleh penutur dengan menggunakan akhiran penutup kalimat (jonggyeol eomi) -a/eora, -a/eo. Tindak tutur memaki dan mengutuk digunakan ketika penutur menginginkan hal buruk untuk terjadi kepada mitra tutur.

Terakhir, tindak tutur mengajak (cheongyu, 청유). Tindak tutur ini digunakan ketika penutur mengajak mitra tutur untuk melakukan suatu hal bersama dengan menggunakan kalimat imperatif.

\section{Ragam Bahasa Kalimat Imperatif}

Dalam bahasa Korea, verba yang berfungsi sebagai predikat selalu ditutup dengan jonggyeol eomi (종결어미) atau akhiran penutup kalimat. Akhiran ini tidak hanya berfungsi untuk menutup sebuah kalimat, tetapi juga berfungsi untuk menentukan jenis kalimat serta menentukan ragam bahasa yang ingin digunakan (Lee \& Ramsey, 2000: 183).

Ragam bahasa adalah cara penyampaian bahasa yang dilakukan oleh penutur berdasarkan tinggi-rendahnya kedudukan mitra tutur (Lee, 2009: 204). Ketika berbahasa atau menyampaikan maksudnya dalam berkomunikasi, seorang penutur selalu menyesuaikan kedudukannya dengan kedudukan mitra tutur. Seperti yang telah dipaparkan sebelumnya, penulis menggunakan teori yang dikemukakan oleh Lee (2005) dan Jeong \& Lee (2005) ini sebagai pedoman untuk mengidentifikasi dan mengklasifikasi ragam bahasa dari data tuturan yang ditemukan dalam penelitian ini. Tabel 2 berikut ini menunjukkan klasifikasi ragam bahasa kalimat imperatif yang diadopsi dari Lee (2005) dan Jeong \& Lee (2005). 
Tabel 2. Ragam Bahasa Kalimat Imperatif

\begin{tabular}{|c|c|c|c|}
\hline Kategori & $\begin{array}{l}\text { Ragam } \\
\text { Bahasa }\end{array}$ & $\begin{array}{c}\text { Akhiran Penutup Kalimat } \\
\text { Imperatif }\end{array}$ & Contoh \\
\hline \multirow{4}{*}{$\begin{array}{l}\text { Ragam } \\
\text { Meninggikan } \\
\text { Mitra Tutur } \\
\text { (nopim, } \\
\text { 높임) }\end{array}$} & $\begin{array}{l}\text { Formal (hapsyoche, } \\
\text { 합쇼체) }\end{array}$ & $\begin{array}{l}\text {-(eu)sipsio ((으)십시오), } \\
-(\mathrm{eu}) \operatorname{soseo}((\text { 으)소서), } \\
-(\mathrm{eu}) \text { eupsoseo ((으)읍소서) }\end{array}$ & $\begin{array}{l}\text { 이리 좀 와 보십시오 } \\
\text { Iri jom wa bo-sipsio } \\
\text { Anda kemarilah }\end{array}$ \\
\hline & $\begin{array}{l}\text { Semiformal (haoche, } \\
\text { 하오체) }\end{array}$ & $\begin{array}{l}-(e u) o \text { ((으)오), -so (소), } \\
\text {-guryeo (구려) }\end{array}$ & $\begin{array}{l}\text { 이리 좀 와 보시오 } \\
\text { Iri jom wa bo-si-o } \\
\text { Anda kemarilah }\end{array}$ \\
\hline & $\begin{array}{l}\text { Informal } \\
\text { santun } \\
\text { (haeyo, } \\
\text { 해요체) }\end{array}$ & $\begin{array}{l}\text {-ayo/eoyo (아요/어요), } \\
\text {-jiyo (지요), -jyo (죠) }\end{array}$ & $\begin{array}{l}\text { 이리 좀 와 봐요 } \\
\text { Iri jom wa bo-ayo } \\
\text { Anda kemarilah }\end{array}$ \\
\hline & $\begin{array}{l}\text { Familiar (hageche, } \\
\text { 하게체) }\end{array}$ & -ge(게), -gena (게나) & $\begin{array}{l}\text { 이리 좀 와 보게 } \\
\text { Iri jom wa bo-ge } \\
\text { Kamu kemarilah }\end{array}$ \\
\hline \multirow[t]{2}{*}{$\begin{array}{l}\text { Ragam Tidak } \\
\text { Meninggikan } \\
\text { Mitra Tutur } \\
\text { (annopim, } \\
\text { 안높임) }\end{array}$} & $\begin{array}{l}\text { Setara (haerache, } \\
\text { 해라체) }\end{array}$ & $\begin{array}{l}\text {-(eu)ryeomuna ((으)려무나), } \\
\text {-(eu)ryeom ((으)렴), } \\
\text {-eora/ara (어라/아라), } \\
\text {-(eu)ra ((으)라) }\end{array}$ & $\begin{array}{l}\text { 이리 좀 와 봐라 } \\
\text { Iri jom wa bo-ara } \\
\text { Kamu kemarilah }\end{array}$ \\
\hline & $\begin{array}{l}\text { Informal (haeche, } \\
\text { 해체) }\end{array}$ & -a/eo (아/어), -ji (지) & $\begin{array}{l}\text { 이리 좀 와 봐 } \\
\text { Iri jom wa bo- } a \\
\text { Kamu kemarilah }\end{array}$ \\
\hline
\end{tabular}

(Sumber: Lee, 2005; Jeong \& Lee, 2005)

Secara garis besar, ragam bahasa dapat dibedakan menjadi dua kategori, ragam bahasa untuk meninggikan mitra tutur (nopim, 높임) dan tidak meninggikan mitra tutur (annopim, 안높임). Kategori pertama terbagi menjadi empat tingkat kesantunan, yakni ragam formal, semiformal, informal santun, dan familiar. Ragam formal (hapsyoche, 합쇼체) adalah ragam bahasa yang paling tinggi dan paling sopan ditandai dengan akhiran penutup kalimat -(eu)sipsio ((으)십시오), -(eu)soseo ((으)소서), -(eu)eupsoseo ((으)읍소서). Ragam ini digunakan ketika penutur dan mitra tutur tidak memiliki hubungan yang akrab. Selain itu, ragam ini digunakan ketika penutur ingin memperlihatkan rasa hormat dan rasa sopannya kepada mitra tutur. Berbeda dengan ragam formal, ragam semiformal (haoche, 하오체) memiliki tingkat kesopanan yang sedikit lebih rendah dibandingkan dengan ragam formal. Ragam ini ditandai dengan akhiran penutup kalimat -(eu)o ((으)오), -so (소), -guryeo (구려). Ragam ini digunakan ketika penutur merasa tidak yakin mitra tutur harus dihormati atau tidak. Ragam ini juga digunakan ketika penutur dan mitra tutur tidak memiliki hubungan yang akrab. Ragam informal santun (haeyoche, 해요체) ini ditandai dengan akhiran penutup kalimat -ayo/eoyo (아요/어요), -jiyo (지요), -jyo (죠). Ragam ini merupakan ragam yang paling sering digunakan. Ragam ini digunakan ketika penutur tidak memiliki hubungan yang sangat akrab tetapi ingin memperlihatkan kedekatan, sedangkan ragam familiar (hageche, 하게체) adalah ragam yang 
biasanya digunakan oleh penutur yang memiliki kedudukan lebih tinggi dibandingkan dengan mitra tutur. Penutur akan menggunakan ragam ini ketika penutur tidak ingin memandang rendah mitra tutur. Ragam ini ditandai dengan akhiran penutup kalimat -ge (게), -gena (게나).

Sementara itu, kategori kedua terbagi menjadi dua tingkat kesantunan, yakni ragam setara dan ragam informal. Ragam setara (haerache, 해라체) memperlihatkan keakraban di antara penutur dan mitra tutur dan ditandai dengan akhiran penutup kalimat -(eu)ryeomuna ((으)려무나), -(eu)ryeom ((으)렴), -eora/ara (어라/아라), -(eu)ra ((으)라). Ragam ini umumnya digunakan oleh orang tua kepada anak, senior yang memiliki hubungan akrab dengan junior, dan antar teman. Kemudian, ragam informal (haeche, 해체) yang digunakan ketika penutur dan mitra tutur memiliki hubungan yang sangat akrab sehingga dapat berkomunikasi dengan santai. Ragam ini tidak dapat digunakan kepada mitra tutur yang baru saja ditemui atau tidak memiliki hubungan yang akrab karena dapat menunjukkan ketidaksopanan. Ragam ini ditandai dengan akhiran penutup $-a / e o$ (아/어), $-j i$ (지).

\section{HASIL PENELITIAN DAN PEMBAHASAN}

Berdasarkan hasil simak-catat, ditemukan 175 tuturan kalimat imperatif dalam dalam film Yeoljeong-gateun Sorihago Iss-ne. Pembahasan hasil penelitian akan dibagi menjadi dua bagian. Bagian pertama mendeskripsikan tindak tutur berwujud kalimat imperatif dalam film Yeoljeonggateun Soriha-go Iss-ne. Bagian kedua mendeskripsikan ragam bahasa yang digunakan dalam tuturan kalimat imperatif berbahasa Korea dalam film tersebut.

\section{Tindak Tutur Berwujud Kalimat Imperatif Berdasarkan Teori Kalimat Imperatif Lee (2016)}

Seperti yang telah disampaikan di atas, ditemukan 175 data tuturan kalimat imperatif dalam korpus film. Berikut ini adalah tabel klasifikasi kalimat imperatif berdasarkan tindak tuturnya berdasarkan teori kalimat imperatif yang dikemukakan oleh Lee (2016).

Berdasarkan Tabel 3, dapat diketahui bahwa kalimat imperatif paling banyak mewujudkan tindak tutur memerintah (jisi, 지시/myeongryeong, 명령), yaitu sebanyak 76 tuturan kalimat imperatif dengan persentase 43,4\%. Kemudian, kalimat imperatif terbanyak kedua mewujudkan tindak tutur meminta (yogu, 요구/yocheong, 요청), yaitu sebanyak 50 tuturan kalimat imperatif dengan persentase $28,6 \%$. Selanjutnya, diikuti oleh tindak tutur memberi persetujuan (heorak, 허락) berjumlah 12 tuturan kalimat imperatif dengan persentase $6,9 \%$, tindak tutur memberi saran (gwongo, 권고/jean, 제안/chunggo, 충고) sebanyak 10 tuturan kalimat imperatif dengan persentase 5,7\%. Lalu, tindak tutur melarang (geumji, 금지) sebanyak 9 tuturan kalimat imperatif dengan persentase $5,1 \%$, tindak tutur memberi peringatan (gyeonggo, 
경고/wihyeop, 위협) sebanyak 9 tuturan kalimat imperatif dengan persentase 5,1\%, tindak tutur memberi salam (chukwon, 축원/insa, 인사) sebanyak 5 tuturan kalimat imperatif dengan persentase $2,9 \%$, dan tindak tutur mengajak (cheongyu, 청유) sebanyak 4 tuturan kalimat imperatif dengan persentase 2,3\%. Dari 11 tindak tutur berwujud kalimat imperatif yang dikemukakan oleh Lee (2005), terdapat 3 tindak tutur yang tidak ditemukan dalam data korpus film Yeoljeong-gateun Sorihago Iss-ne ini, yaitu tindak tutur memberi keluasaan (yangbo, 양보), tindak tutur memperlihatkan harapan (giwon, 기원), serta tindak tutur memaki dan mengutuk (jeoju, 저주).

Tabel 3. Klasifikasi Kalimat Imperatif Berdasarkan Tindak Tuturnya

\begin{tabular}{lcc}
\hline \multicolumn{1}{c}{ Tindak Tutur } & Jumlah & Persentase \\
\hline Memerintah (jisi, 지시/myeongryeong, 명령) & 76 & $43,4 \%$ \\
Meminta (yogu, 요구/yocheong, 요청) & 50 & $28,6 \%$ \\
Memberi persetujuan (heorak, 허락) & 12 & $6,9 \%$ \\
Memberi saran (gwongo, 권고/jean, 제안/chunggo, 충고) & 10 & $5,7 \%$ \\
Melarang (geumji, 금지) & 9 & $5,1 \%$ \\
Memberi peringatan (gyeonggo, 경고/wihyeop, 위협) & 9 & $5,1 \%$ \\
Memberi salam (chukwon, 축원/insa, 인사) & 5 & $2,9 \%$ \\
Mengajak (cheongyu, 청유) & 4 & $2,3 \%$ \\
Memberi keleluasaan (yangbo, 양보) & 0 & $0 \%$ \\
Memaki dan mengutuk (jeoju, 저주) & 0 & $0 \%$ \\
Memperlihatkan harapan (giwon, 기원) & 0 & $0 \%$ \\
\hline
\end{tabular}

(Sumber: Data penelitian penulis)

(3) 우지한 관련 된 건 전부 네가 맡아.

Woo Jihan gwallyeon geon jeonbu nega mat-a.

Kamu bertanggung jawab mengenai semua hal yang berkaitan dengan Woo Jihan.

Tuturan (3) diucapkan oleh $\mathrm{Ha}$ Jaegwan yang merupakan seorang kepala divisi hiburan. Lalu, yang menjadi mitra tutur adalah Do Rahui, tokoh utama yang merupakan seorang pemagang di divisi hiburan. Tuturan (3) ini diucapkan oleh $\mathrm{Ha}$ Jaegwan setelah Do Rahui menulis artikel yang mendapat banyak pembaca mengenai Woo Jihan, seorang selebriti. Tuturan (3) ini memperlihatkan bahwa $\mathrm{Ha}$ Jaegwan memerintahkan Do Rahui untuk mengemban tanggung jawab dengan semua hal yang berhubungan dengan Woo Jihan. Tuturan (3) ini menggunakan tindak tutur memerintah (jisi, 지시/myeongryeong, 명령) berwujud kalimat imperatif karena penutur tidak memiliki maksud lain, selain memerintah mitra tutur.

(4) 다른 분한테도 그렇게 애기하시구요.

Dareun bun-hante-do geureotge 
yaegi-hasigu-yo.

Tolong katakan seperti itu kepada orang lain juga.

Pada tuturan (4), penutur adalah Do Rahui dan mitra tutur adalah seorang manajer seorang artis. Situasi yang digambarkan ketika tuturan ini diucapkan adalah Do Rahui yang sedang berusaha membuat manajer seorang artis untuk memberikan keterangan yang sama seperti yang manajer itu berikan kepada Do Rahui mengenai kecelakaan yang dialaminya bersama artis terkenal. Tuturan (4) ini masuk ke dalam tindak tutur meminta (yogu, 요구/yocheong, 요청) berwujud kalimat imperatif karena ekspresi wajah yang diperlihatkan dan intonasi bicara yang digunakan oleh Do Rahui memperlihatkan sebuah permintaan.

(5) 까는 소리하지 말라 그래.

Kka-neun soriha-ji malla geurae.

Jangan bicara seperti itu.

Situasi ketika tuturan (5) ini dituturkan adalah ketika divisi hiburan ingin mengunggah artikel kebenaran mengenai Woo Jihan yang dituduh melakukan kekerasan seksual oleh presiden perusahaan hiburan tempat Woo Jihan bernaung. Ha Jaegwan selaku penutur mengucapkan tuturan tersebut kepada semua bawahannya untuk melarang direktur berbicara mengenai divisi hiburan yang dilarang untuk mengunggah artikel tersebut karena takut kehilangan sponsor perusahaan. Tindak tutur kalimat imperatif pada tuturan
(5) adalah tindak tutur melarang, dapat dilihat dari penggunaan ji ma yang memiliki arti 'jangan'.

(6) 간경화 그렇게 만만한 병 아니야. 술 끊 어야 돼.

Gangyeonghwa geureotge manmanhan byeong aniya. Sul kkeun-eoya dwae.

Sirosis hati bukan penyakit sembarangan. Kamu harus berhenti minum.

Tuturan (6) adalah tuturan yang menggunakan tindak tutur memberi saran (gwongo, 권고/jean, 제안/chunggo, 충고) berwujud kalimat imperatif. Hal ini dilihat dari tuturan kalimat imperatif yang diucapkan oleh penutur memiliki maksud yang baik untuk mitra tutur. Penutur dalam tuturan (6) ini adalah adik ipar Ha Jaegwan yang merupakan seorang dokter. Adik ipar Ha Jaegwan ini memberi saran untuk berhenti meminum minuman keras kepada Ha Jaegwan, selaku mitra tutur ketika berkonsultasi mengenai penyakitnya. Saran ini diberikan kepada Ha Jaegwan yang memiliki penyakit sirosis hati akut supaya penyakitnya tidak menjadi lebih serius dan Ha Jaegwan dapat menjalani hidup sehat.

(7) 그 때로 돌아가고 싶지 않으시면 이쯤에 서 그만 하시죠.

Geu ddae-ro doragago sip-ji aneusimyeon ijjeum-eseo geuman hasi-jyo. Berhenti di sini jika anda tidak mau kembali ke masa itu. 
Tuturan (7) merupakan tuturan yang menggunakan tindak tutur memberi peringatan (gyeonggo, 경고/wihyeop, 위협) berwujud kalimat imperatif karena penutur menuturkan tuturan ini dengan nada bicara mengancam. Tuturan (7) ini diucapkan oleh Woo Jihan selaku penutur kepada Jang Yujin, seorang presiden perusahaan hiburan selaku mitra tutur karna ia tidak ingin pergi ke Amerika seperti yang diperintahkan oleh Jang Yujin. Jika Jang Yujin terus memaksa Woo Jihan untuk pergi, Woo Jihan memberi peringatan dan juga mengancam Jang Yujin dengan cara akan keluar dari perusahaan yang Jang Yujin pimpin sehingga Jang Yujin kembali ke masa sulit seperti masa sebelum Woo Jihan masuk ke perusahaan Jang Yujin.

(8) 그건 알아서 하시고요.

Geugeon araseo hasigo-yo.

Silahkan saja.

Tuturan (8) merupakan tuturan yang menggunakan tindak tutur memberi persetujuan (heorak, 허락) berwujud tuturan imperatif karena penutur memperbolehkan mitra tutur melakukan hal yang ingin ia lakukan. Tuturan ini diucapkan oleh Do Rahui ketika Jang Yujin yang akan melaporkan Do Rahui kepada polisi dengan tuduhan pencemaran nama baik. Hal ini terjadi karena di depan para wartawan, Do Rahui berani menceritakan kejahatan Jang Yujin yang telah membayar seorang perempuan untuk mengaku menjadi korban kekerasan seksual Woo Jihan. Tuturan (8) ini memperlihatkan bahwa Do Rahui mempersilahkan atau memberikan izin kepada Jang Yujin untuk melaporkannya kepada polisi.

(9) 잘 가.

Jal ga.

Selamat tinggal.

Tuturan (9) merupakan kalimat imperatif yang mewujudkan tindak tutur memberi salam (chukwon, 축원/insa, 인사) karena penutur menuturkan tuturan kalimat ini sebagai salam perpisahan. Tuturan (9) ini diucapkan Do Rahui (penutur) kepada Seojin (mitra tutur), kekasih Do Rahui yang akan pergi ke luar negeri untuk bekerja. Tuturan ini diucapkan ketika Do Rahui melepas kepergian Seojin ketika di bandara. Tuturan ini merupakan harapan baik dan salam yang banyak digunakan di Korea.

(10) 자자 얼른 가시죠. 제가 좋은 데로 모시 겠습니다.

Jaja eolleun gasi-jyo. Jega jouen de-ro moeusi-gess-seubnida.

Ayo cepat kita pergi. Saya akan antar ke tempat yang bagus.

Tuturan (10) memiliki tindak tutur mengajak (cheongyu, 청유) berwujud kalimat imperatif karena tuturan ini dituturkan oleh penutur kepada mitra untuk melakukan suatu hal bersama-sama. Tuturan ini diucapkan oleh Jang Yujin ketika mengajak Ha Jaegwan untuk cepat pergi ke tempat yang lebih bagus setelah mereka melakukan pertemuan untuk membuat kesepakatan untuk berhenti menulis artikel yang dapat mencemarkan 
nama baik Woo Jihan. Tuturan kalimat imperatif ini dikatakan memiliki tindak tutur mengajak karena Jang Yujin selaku penutur juga pergi bersama Ha Jaegwan yang merupakan mitra tutur.

\section{Ragam Kalimat Imperatif dalam Film Yeoljeong-gateun Soriha-go Iss-ne}

Seperti yang sudah disampaikan di atas, ragam kalimat imperatif dapat diidentifikasi melalui akhiran penutup kalimat yang digunakan oleh penutur ketika menuturkan tuturan kalimat imperatif. Tabel 4 adalah tabel klasifikasi ragam kalimat imperatif berdasarkan teori ragam bahasa dalam bahasa Korea.

Tabel 4 menunjukkan, ragam kalimat imperatif yang paling banyak digunakan adalah ragam informal (haeche, 해체), yaitu sebanyak 132 tuturan kalimat imperatif dengan persentase 75,4\%. Selanjutnya, ragam bahasa kedua yang sering digunakan adalah ragam informal santun (haeyoche, 해요체) sebanyak 24 tuturan kalimat imperatif dengan persentase 13,7\%. Kemudian, diikuti oleh ragam setara (haerache, 해라체) sebanyak 12 tuturan kalimat imperatif dengan persentase 6,9\%, ragam formal (hapsyoche, 합쇼체) sebanyak 4 tuturan kalimat imperatif dengan persentase 2,3\%, dan ragam familiar (hageche, 하게체) sebanyak 3 tuturan kalimat imperatif dengan persentase $1,7 \%$. Dari film yang berdurasi 106 menit ini, penulis tidak menemukan penggunaan ragam bahasa semiformal (haoche, 하오체).

Tabel 4. Ragam Kalimat Imperatif dalam Bahasa Korea

\begin{tabular}{|c|c|c|c|c|}
\hline Kategori & $\begin{array}{c}\text { Ragam Bahasa } \\
\text { Korea }\end{array}$ & Akhiran Penutup Kalimat & Jumlah & Persentase \\
\hline \multirow{4}{*}{$\begin{array}{c}\text { Ragam } \\
\text { Meninggikan } \\
\text { Mitra Tutur } \\
\text { (nopim, } \\
\text { 높임) }\end{array}$} & $\begin{array}{l}\text { Formal } \\
\text { (hapsyoche, } \\
\text { 합쇼체) }\end{array}$ & $\begin{array}{l}-(\mathrm{eu}) \operatorname{sipsio}((\text { 으)십시오 }), \\
-(\mathrm{eu}) \operatorname{soseo}((\text { 으)소서), } \\
\text {-(eu)eupsoseo ((으)읍소서) }\end{array}$ & 4 & $2,3 \%$ \\
\hline & $\begin{array}{l}\text { Semiformal } \\
\text { (haoche, } \\
\text { 하오체) }\end{array}$ & $\begin{array}{l}-(e u) o((\text { 으)오), -so (소), } \\
\text {-guryeo (구려) }\end{array}$ & 0 & $0 \%$ \\
\hline & $\begin{array}{l}\text { Informal santun } \\
\text { (haeyoche, } \\
\text { 해요체) }\end{array}$ & $\begin{array}{l}\text {-ayo/eoyo (아요/어요), } \\
\text {-jiyo (지요), -jyo (죠) }\end{array}$ & 24 & $13,7 \%$ \\
\hline & $\begin{array}{l}\text { Familiar } \\
\text { (hageche, } \\
\text { 하게체) }\end{array}$ & -ge (게), -gena (게나) & 3 & $1,7 \%$ \\
\hline \multirow[t]{3}{*}{$\begin{array}{l}\text { Ragam Tidak } \\
\text { Meninggikan } \\
\text { Mitra Tutur } \\
\text { (annopim, 안높 } \\
\text { 임) }\end{array}$} & $\begin{array}{l}\text { Setara (haerache, } \\
\text { 해라체) }\end{array}$ & $\begin{array}{l}\text {-(eu)ryeomuna ((으)려무나), } \\
\text {-(eu)ryeom ((으)렴), } \\
\text {-eora/ara (어라/아라), } \\
\text {-(eu)ra ((으)라) }\end{array}$ & 12 & $6,9 \%$ \\
\hline & $\begin{array}{l}\text { Informal (haeche, } \\
\text { 해체) }\end{array}$ & $-a / e o$ (아/어), $-j i$ (지) & 132 & $75,4 \%$ \\
\hline & \multicolumn{2}{|c|}{ Total } & 175 & $100 \%$ \\
\hline
\end{tabular}


(11) 아이고 걱정마십시오. Aigo, geokjeongma-sipsio.

Aduh, Anda jangan khawatir.

Tuturan ini menggunakan ragam yang paling tinggi, yaitu ragam formal (hapsyoche, 합쇼체). Penutur menggunakan ragam ini untuk menunjukkan rasa hormatnya kepada mitra tutur. Tuturan (11) merupakan contoh tuturan kalimat imperatif dengan ragam bahasa formal yang digunakan oleh Ha Jaegwan ketika berbicara dengan atasannya melalui sambungan telepon. Ha Jaegwan meminta supaya atasannya untuk tidak khawatir dengan hal yang ia telah lakukan, yaitu mengunggah sebuah artikel berita yang mendapat banyak perhatian dari pengguna internet. Ha Jaegwan menunjukkan rasa hormatnya kepada atasannya dengan menggunakan ragam hormat untuk memberi perintah.

Ragam bahasa selanjutnya yang ditemui oleh penulis adalah ragam informal santun (haeyoche, 해요체). Ragam ini merupakan ragam bahasa kedua yang sering digunakan. Berikut adalah tuturan kalimat imperatif yang menggunakan ragam hormat.

(12) 제발 좀 말씀해 주세요.

Jebal jom malsseumhae ju-seyo.

Tolong bicaralah.

Tuturan (12) adalah tuturan kalimat imperatif yang diucapkan oleh Do Rahui kepada manajer sebuah grup idola yang mengalami kecelakaan mobil. Tuturan ini diucapkan Do Rahui ketika meminta manajer untuk memberikan informasi terkait anggota grup idola yang mengalami patah tulang. Do Rahui menggunakan ragam ini karena ia tidak memiliki hubungan yang akrab tetapi ingin terlihat lebih santai.

(13) 너 이제 월급 받으니까 오빠 싼 거 좀 사 게.

Neo ije wolgeub bad-eunikka oppa ssan geo jom sa-ge.

Kamu sekarang sudah mendapat gaji. Jadi, belikan aku sesuatu yang murah.

Tuturan (13) adalah tuturan kalimat imperatif yang menggunakan ragam familiar (hageche, 하게체). Tuturan ini diucapkan oleh seorang senior di tempat Do Rahui bekerja. Senior tersebut menggunakan ragam ini karena tidak ingin terlihat merendahkan Do Rahui yang merupakan seorang pemagang.

(14) 이거 검토해보고 내일 오전까지 기사 를 작서해라.

Igeo geomtohaebo-go naeil ojeonkkaji gisa-reul jakseohae-ra.

Kamu periksa ini dan tulis sebuah artikel sampai besok pagi.

Tuturan (14) adalah tuturan yang menggunakan ragam setara (haerache, 해라체). Tuturan kalimat imperatif ini diucapkan oleh Ha Jaegwan kepada Do Rahui. Ia menggunakan ragam bahasa ini 
karena ia yang merupakan atasan merasa telah memiliki hubungan akrab dengan Do Rahui sebagai bawahannya.

(15) 네가 빨리 강병으로 출동해.

Nega ppalli gangbyeong-euro chuldonghae.

Kamu cepat berangkat ke rumah sakit Kang.

Tuturan (15) merupakan tuturan kalimat imperatif yang diucapkan oleh $\mathrm{Ha}$ Jaegwan kepada Do Rahui yang menggunakan ragam informal (haeche, 해체). Ha Jaegwan menggunakan ragam ini untuk menimbulkan kesan santai dalam hubungan antara atasan dengan bawahan.

\section{KESIMPULAN}

Berdasarkan hasil analisis data korpus film Yeoljeong-gateun Soriha-go Iss-ne ditemukan 175 tuturan kalimat imperatif. Dari 11 tindak tutur yang dikemukakan oleh Lee (2016), hanya ditemukan 8 tindak tutur. Tindak tutur tersebut adalah tindak tutur memerintah (jisi, 지시/myeongryeong, 명령), tindak tutur meminta (yogu, 요구/yocheong, 요청), tindak tutur melarang (geumji, 금지), tindak tutur memberi saran (gwongo, 권고/jean, 제안/chunggo, 충고), tindak tutur memberi peringatan (gyeonggo, 경고/wihyeop, 위협), tindak tutur memberi persetujuan (heorak, 허락), tindak tutur memberi salam (chukwon, 축원/insa, 인사), dan tindak tutur mengajak (cheongyu, 청유). Tindak tutur yang paling banyak diwujudkan adalah tindak tutur memerintah (jisi, 지시/myeongryeong, 명령) sebanyak $76(43.4 \%)$ tuturan kalimat imperatif.

Selanjutnya, penulis menemukan 5 ragam bahasa yang digunakan dalam film Yeoljeong-gateun Soriha-go Iss-ne. Ragam formal (hapsyoche, 합쇼체) digunakan sebanyak 4 tuturan kalimat imperatif, ragam informal santun (haeyoche, 해요체) sebanyak 24 tuturan kalimat imperatif, ragam familiar (hageche, 하게체) sebanyak 3 tuturan kalimat imperatif, ragam setara (haerache, 해라체) sebanyak 12 tuturan kalimat imperatif, dan ragam informal (haeche, 해체) sebanyak 132 tuturan kalimat imperatif. Dari ragam bahasa yang ditemukan, ragam informal (haeche, 해체) merupakan ragam bahasa yang paling sering digunakan, yaitu sebanyak 132 kali. Ragam informal (haeche, 해체) paling banyak digunakan karena ragam ini paling banyak dituturkan oleh seseorang yang memiliki jabatan tinggi, misalnya manajer kepada karyawan biasa. Film Yeoljeonggateun Soriha-go Iss-ne menggambarkan seorang manager yang lebih senang menggunakan ragam informal kepada karyawan biasa, termasuk kepada seorang pemagang yang baru dikenalnya.

Dalam penelitian ini, penulis hanya berfokus pada tindak tutur yang berwujud kalimat imperatif. Sampai saat ini belum banyak penelitian yang mengkaji bahasa Korea dengan menggunakan korpus, yang merupakan celah akademis yang bisa diisi oleh penelitian selanjutnya. Korpus yang lebih beragam dapat digunakan oleh penelitian selanjutnya guna mengkaji tindak tutur dalam bentuk kalimat lain. 


\section{DAFTAR PUSTAKA}

$\mathrm{Gu}$, Y.E. et al. (2018). Hangugeo Sueop

Daehwaui Hwahaeng Bunseokgwa Hwahaeng Jadongbunryureul Wihan Eoneohakjeok Gibanyeongu. Journal of KIISE 45. 807-815. Diakses melalui http://kiise.or.kr/e journal/2018/8/JOK/ pdf/08.pdf pada 2 April 2020.

Im, H.B. (1987). Gugeo Bujeongmunui Tongsawa Uimi. Gugeosaenghwal. 7299. Diakses melalui https://www.korean.go.kr/nkview/nklife/ 1987 3/1987 0307.pdf pada 2 April 2020.

Jeong, J.S. \& Lee, P.Y. (2005).

Ganjeobhwahaeng Pandanui Jemunje. Journal of Korean Language and Culture. 28. 47-68. Diakses melalui http://portal.jams.or.kr/uci/artView?art_i $\mathrm{d}=$ ART001154077\&search type $=2$ pada 20 Maret 2020.

Keraf, G. (1997). Komposisi: Sebuah

Pengantar Kemahiran Bahasa. Penerbit Nusa Indah.

Lee, E.H. (2009). Sangdae Nopim Hwagyee

Daehan Yeongu. Dalam Kim, J.H (Ed.).

Gugeo Munbeobui Tamgu 2: Gugeo

Nopimbeob Pyohyeonui Baldal (hal. 203-234). Bakmunsa.

Lee, G.G. (2005). Gugeo Gyoyugeul Wihan

Gugeo Munbeobron. Jipmundang.

Lee, I.S. \& Ramsey, S. R. (2000). The Korean Language. State University of New York.
Lee, J.S.
(2016).
Hangugeo

Myeongryeongmunui Munbeobgwa Hwahaeng Yeongu. Seoul University. Diakses melalui http://sspace.snu.ac.kr/bitstream/10371/121717 /1/000000137415.pdf pada 4 Maret 2020. Nam, G.S. \& Go Y.G. (1985). Pyojun Gugeo Munbeobron. Tapchulpansa.

Qonita, I.G. \& Usmi. (2019). Kajian Tindak Tutur Memerintah Bahasa Korea dalam Drama The Beauty Inside. International University Symposium on Humanities and Arts (Inusharts). 4. 152-163.

Quirk, R. et al. (1985). A Comprehensive Grammar of the English Language. Longman.

Rahardi, K. 2005. Pragmatik, Kesantunan Imperatif Bahasa Indonesia. Erlangga.

Seo, Y.M. (Writer), Jeong, G.H. (Director). (2015). You Call It Passion [Movie]. South Korea: NEW.

Xia, Qi. (2013). A Study on Education Program of Korean Imperative Sentence: Focusing on Speech Acts of Korean Imperative Sentence. Cheongju University. Diakses melalui http://cju.dcollection.net/srch/srchDetail /000001560281 pada 31 Maret 2020.

Yu, H.R. (2009). Hangugeo Gyoyukeseo 'Hwahaeng'e Daehan Bipanjeok Geomto. Hangugeogyoyuk. 20. 107-127. Diakses melalui https://www.dbpia.co.kr/Journal/article Detail?nodeId=NODE09113877 pada 2 April 2020 